\title{
URGENSI PENDIDIKAN MULTIKULTURAL UNTUK MENUMBUHKAN NILAI TOLERANSI AGAMA DI INDONESIA
}

\author{
Eka Prasetiawati \\ Institut Agama Islam Ma'arif (IAIM) NU Metro \\ prasetyaeka41@gmail.com
}

\begin{abstract}
Abstrak
Indonesia memiliki kemajemukan suku bangsa dan agama. Kemajemukan suku ini merupakan salah satu ciri masyarakat Indonesia yang patut dibanggakan. Akan tetapi, tanpa kita sadari bahwa kemajemukan tersebut juga menyimpan potensi konflik yang dapat mengancam kehidupan berbangsa dan bernegara. Prinsip keberagamaan masing-masing kelompok mudah menimbulkan konflik. Bahkan manifestasi multikultaralisme itu bisa merambah pada wilayah etnis, budaya, bahasa, agama, keyakinan, pola pikir maupun kemampuan. Perbedaan tersebut sekiranya tidak diantisipasi akan menjadi pemicu konflik yang berujung pada kekerasan bahkan pertumpahan darah. Tujuan penelitian ini untuk membangun wacana multikultural di kalangan guru dan siswa tidak hanya pada mata pelajaran tetapi mampu menerapkan nilai-nilai pluralisme, humanisme dan demokrasi secara langsung di sekolah sehingga bangsa ini mampu menghadapi berbagai bentuk konflik sosial. Hasil penelitian ini adalah implementasi di sekolah, dalam konteks pembelajaran perlu dilakukan pendekatan integratif learning model (guru mengorganisasi materi dengan mengaitkan beberapa tema dari berbagai mata pelajaran yang relevan); guru mempunyai strategi pembelajaran yang relevan seperti student centered instruction melalui diskusi, simulasi dan game; penguatan pendidikan karakter di sekolah seperti religius, nasionalis, mandiri, gotong royong dan integritas; menumbuhkan nilai-nilai toleransi agama di sekolah seperti siswa meneladani sikap guru ketika bergaul dengan sesama guru atau siswa yang berbeda agama; dalam kehidupan masyarakat siswa tidak membedakan menolong teman yang sakit, bergotong royong, dan tidak mengejek ibadah teman satu dengan yang lain.
\end{abstract}

Kata kunci. Pendidikan, Multikultural, Nilai toleransi.

\begin{abstract}
Indonesia has a plurality of tribes and religions. The plurality of this tribe is the characteristics of Indonesian society to be proud. However, we not realized that the plurality also holds potential conflicts that can threaten the life of nation and state. The religious principle of each group is easy to cause conflict. Even the manifestations of multiculturalism can penetrate ethnic, cultural, linguistic, religious, belief, mindset and ability areas. The differences are not anticipated to be a trigger of conflict that leads to violence and bloodshed. The purpose of this research is to build multicultural discourse among teachers and students not only on subjects but also able to apply the values of pluralism, humanism and democracy directly in school so the nations able to face various of social conflicts. The result of this research is implementation in school, in the context of learning needs to be done integrative approach of learning model (teacher organize material by relating some theme from various relevant subjects); teachers have relevant learning strategies such as student centered instruction through
\end{abstract}


discussions, simulations and games; strengthening character education in schools such as religious, nationalist, independent, gotong royong and integrity; growing religious tolerance values in schools such as students imitating the attitude of teachers when mixing with teachers or students of different religions; In the life, student does not distinguish helping friends who are sick, cooperate, and not mocking the worship of friends with one another.

Keywords. Education, Multicultural, Tolerance Value.

\section{A. Pendahuluan}

Toleransi beragama merupakan ciri kemajemukan bangsa Indonesia. Oleh karena itu masyarakat seharusnya memelihara budaya toleransi ini bukan merusaknya. Di tengah masyarakat majemuk, modal utama menciptakan kerukunan adalah menegakkan toleransi. Dengan memelihara sikap seperti itu, maka tindakan intoleransi bisa berkurang bahkan hilang sama sekali. Banyak peristiwa yang terjadi akhir-akhir ini disebabkan oleh kurangnya sikap toleransi bangsa kita. Faktor penting lainnya yaitu pendidikan masyarakat kita sangat kurang, kebanyakan mereka lebih memilih bekerja dari pada bersekolah.

Keberagaman budaya di Indonesia merupakan kenyataan historis dan sosial yang tidak dapat disangkal oleh siapapun. Keunikan budaya yang beragam tersebut memberikan implikasi pola pikir, tingkah laku dan karakter pribadi masing-masing sebagai sebuah tradisi yang hidup dalam masyarakat dan daerah. Tradisi yang terbentuk akan berlainan dari satu suku dengan suku yang lain. Pergumulan antar budaya memberikan peluang konflik manakala tidak terjadi saling memahami dan menghormati satu sama lain. Proses untuk meminimalisir konflik inil memerlukan upaya pendidikan yang berwawasan multikultural dalam rangka pemberdayaan masyarakat yang majemuk dan heterogen agar saling memahami dan menghormati serta membentuk karakter yang terbuka terhadap perbedaan. ${ }^{1}$

Azyumardi Azra menegaskan bahwa Indonesia menyadari tentang kemajemukan ragam etnik dan budaya masyarakatnya. Indonesia diproklamirkan sebagai sebuah negara yang memiliki keragaman etnik tetapi memiliki tujuan yang sama, yakni menuju masyarakat adil makmur dan sejahtera. Akan tetapi, gagasan

1 H.A.R.Tilaar, Multikulturalisme:Tantangan-Tantangan Global Masa Depan Dalam Transformasi Pendidikan Nasional, (Jakarta:Grasindo2004), h. 9-10 
besar tersebut kemudian tenggelam dalam sejarah dengan politik mono-kulturnya di zaman Soekarno dan Soeharto. Demokrasi terpimpin telah mematikan kreativitas lokal daerah yang berbasis etnik dan budaya tertentu. Demikian pula dengan manajemen pemerintahan sentralistik zaman Soeharto, sehingga falsafah Bhinneka Tunggal Ika kemudian hanya menjadi slogan tetapi tidak pernah mewujud dalam teori ketata negaraan, hubungan sosial maupun pranata sosial lainnya. Ketika simpul-simpul yang mengikat demokratisasi itu dibuka pada zaman reformasi, maka gagasan multikulturalisme kini mengemuka dan langsung memasuki wilayah pendidikan.

Kerukunan beragama di tengah keanekaragaman budaya merupakan aset dalam kehidupan berbangsa dan bernegara di Indonesia. Dalam perjalanan sejarah bangsa, pancasila telah teruji sebagai alternatif yang paling tepat untuk mempersatukan masyarakat Indonesia yang sangat majemuk di bawah suatu tatanan yang inklusif dan demokratis. Sayangnya wacana mengenai pancasila seolah lenyap seiring dengan berlangsungnya reformasi. Berbagai kendala sering kita hadapi dalam menciptakan kerukunan (toleransi) umat beragama. Dari berbagai pihak telah sepakat untuk mencapai tujuan kerukunan beragama di Indonesia seperti masyarakat dari berbagai golongan, pemerintah, dan organisasi agama yang banyak berperan aktif dalam masyarakat.

Indonesia sebagaimana dikuatkan oleh para ahli yang memiliki perhatian besar terhadap pendidikan multietnik, justru menjadikan multikulturalisme sebagai common platform dalam mendesain pembelajaran yang berbasis Bhinneka Tunggal Ika, bahkan nilai-nilai tersebut diupayakan melalui mata pelajaran kewarganegaraan dan didukung pula oleh pendidikan agama. ${ }^{2}$

Indonesia adalah salah satu negara multikultural terbesar di dunia. Terlihat dari keadaan sosio-kultural yang begitu beragam, populasi penduduk yang besar dan memiliki 300 suku bangsa. Selain itu mereka juga menganut agama dan kepercayaan yang berbeda mulai dari Islam, Katolik, Protestan, Hindu, Budha, Konghucu serta berbagai macam aliran kepercayaan ${ }^{3}$. Keragaman tersebut disadari atau tidak dapat

2 Azyumardi Azra, Pendidikan Multikultural: Membangun Kembali Indonesia Bhinneka Tunggal Ika, dalam Tsaqafah, Vol. I, No. 2, 2003, h. 19

${ }^{3}$ M.Ainul Yaqin, Pendidikan Multikultural; Cross-Cultural Understanding untuk Demokrasi dan Keadilan, (Yogyakarta: Pilar Media, 2007), h. 4 
menimbulkan berbagai persoalan yang sekarang dihadapi bangsa ini. Korupsi, kolusi, nepotisme, perseteruan politik, kemiskinan, kekerasan, separatisme, perusakan lingkungan dan hilangnya rasa kemanusiaan untuk menghormati hak orang lain adalah bentuk nyata dari multikulturalisme itu.

Menurut Sasanto Wibisono, problematika penyimpangan perilaku yang mengesampingkan nilai-nilai moral dan etika seperti korupsi, kolusi, nepotisme, pemerasan, tindak kekerasan, malpraktek dan perusakan lingkungan adalah disebabkan oleh akulturasi dan urbanisasi. Kondisi perekonomian dan politik yang tidak sehat bisa memperparah keadaan ini. Untuk merubah keadaan ini harus dilakukan melalui dunia pendidikan dengan cara memperbaiki sumber pembelajarannya. Sekolah dapat merubah perilaku peserta didik secara bertahap dengan menerapkan materi pembelajaran untuk meningkatkan kualitas normatif perilaku seperti aspek moralitas, disiplin, kepedulian humanistik, kejujuran etika dan lain-lain. ${ }^{4}$

Berkaitan dengan hal tersebut, maka pendidikan multikultural menawarkan alternatif melalui penerapan dan konsep pendidikan yang berbasis pada pemanfaatan keragaman yang ada di masyarakat seperti keragaman etnis, budaya, bahasa, agama, status sosial, gender, kemampuan, umur dan ras. Dan yang terpenting, strategi pendidikan ini tidak hanya bertujuan agar siswa mudah memahami pelajaran yang dipelajari, akan tetapi untuk meningkatkan kesadaran mereka agar selalu berperilaku humanis, pluralis dan demokratis. Hal terpenting dalam pendidikan multikultural ini adalah seorang guru tidak hanya di tuntut menguasai dan mampu secara profesional mengajar mata pelajaran yang diajarkannya. Lebih dari itu seorang pendidik juga harus mampu menanamkan nilai-nilai inti dari pendidikan multikultural seperti demokrasi, humanisme dan pluralisme.

Sementara pendidikan Islam baik sebagai lembaga dan materi dikritik telah mempraktikkan proses pendidikan yang eksklusif, dogmatif dan kurang menyentuh apek moralitas. Proses pendidikan seperti ini terjadi di lembaga-lembaga Islam, seperti sekolah Islam, madrasah dan pesantren. Indikatornya, menurut Amin Abdullah terlihat pada proses pendidikan dan pengajaran agama pada umumnya yang lebih

\footnotetext{
4 Ibid, h. 27
} 
menekankan sisi keselamatan individu dan kelompoknya sendiri dari keselamatan orang lain. ${ }^{5}$

Kerukunan bangsa kita belakangan ini menjadi terancam dan keutuhan bangsa pun terkoyak menyusul sejumlah fakta kerusuhan sosial yang membara di di tanah air, dipicu oleh masalah SARA (suku, agama, ras, dan antar golongan) yang sangat kompleks. Terlepas dari berbagai analisis tentang apakah akar konflik sosial itu terletak pada wilayah ekonomi, politik, sosial, budaya, etnis atau agama. Karena itu, ketika toleransi tidak dihargai oleh masyarakat, maka muncul sebuah pertanyaan apa yang salah dengan sistem sosial-budaya kita? Apakah sistem pendidikan kita tidak memiliki ruang cukup bagi tumbuhnya semangat toleransi? Lalu, model pendidikan yang bagaimana yang mampu menumbuhkan toleransi agama?

Melalui pendidikan, nilai apa yang relevan ditumbuhkan pada peserta didik agar mereka mengapresiasi keberagaman? Adakah kemungkinan perumusan ulang kurikulum pendidikan nasional yang mendorong tumbuh nya nilai toleransi agama.

Kondisi pendidikan di Indonesia termasuk pendidikan Islamnya, menurut pakar pendidikan tidak memadai lagi untuk masyarakat Indonesia yang plural dan multikultural. Oleh karena itu, perlu dilakukan transformasi paradigma pendidikan di Indonesia. Adapun paradigma pendidikan yang ditawarkan adalah pendidikan multikultural sebagai pengganti pendidikan monokultural.

\section{Rumusan Masalah}

a. Bagaimanakah urgensi pendidikan multikultural di Indonesia?

b. Bagaimanakah implementasi pendidikan multikultural di Indonesia untuk menumbuhkan nilai toleransi agama?

\section{Tujuan dan Manfaat Penelitian}

a. Untuk mengetahui urgensi pendidikan multikultural di Indonesia.

b. Untuk mengetahui implementasi pendidikan multikultural di Indonesia dalam menumbuhkan nilai toleransi agama.

${ }^{5}$ M.Amin Abdullah, Pengajaran Kalam dan Teologi di Era Kemajemukan: Sebuah Tinjauan Materi dan Metode Pendidikan Agama, dalam Tashwirul Afkar, Jurnal Refleksi Pemikiran Keagamaan \& Kebudayaan, No.11 Th. 2001, h. 14 
c. Untuk menambah khazanah pengetahuan tentang pendidikan multikultural di Indonesia.

d. Sebagai masukan/bahan pertimbangan bagi pengelola pendidikan untuk mengembangkan pendidikan multikultural.

\section{Metodologi Penelitian}

a. Pendekatan dan Jenis Penelitian

Jenis penelitian yang digunakan dalam penelitian ini adalah kepustakaan (Library Research) dimana penulis menggunakan pendekatan penelitian normatif deskriptif dengan lebih menekankan pada kekuatan analisis data pada sumber-sumber data yang ada. Yang dimaksud dengan studi kepustakaan adalah segala usaha yang dilakukan oleh peneliti untuk menghimpun informasi yang relevan dengan topik atau masalah yang akan atau sedang diteliti. Informasi itu dapat diperoleh dari buku-buku ilmiah, laporan penelitian, karangan-karangan ilmiah, tesis, disertasi, peraturanperaturan, ketetapan-ketetapan, buku tahunan, ensiklopedia, dan sumbersumber tertulis lain baik tercetak maupun elektronik. ${ }^{6}$

b. Sumber Data

Sumber-sumber data dapat dibagi menjadi dua kategori, yaitu sumber data primer dan skunder. Sumber data primer dalam penelitian ini adalah buku Pendidikan Multikultural; Cross-Cultural Understanding untuk Demokrasi dan Keadilan Karya M.Ainul Yaqin, buku Pendidikan Islam Multikultural di Pesantren karya Abdullah Aly. Adapun sumber skundernya adalah segala informasi yang berkaitan dengan tema penelitian ini, baik berupa buku maupun artikel-artikel yang tersebar di berbagai makalah, jurnal, dan web-site.

c. Teknik Pengumpulan Data

Pengumpulan data dalam penelitian ini dilakukan dengan teknik dokumentasi. Teknik ini digunakan untuk melacak dokumen, data dan informasi baik yang berupa buku, majalah, jurnal ilmiah, artikel, dan lain sebagainya yang relevan dengan penelitian ini.

${ }^{6}$ Purwono, "Kajian Kepustakaan", dalam http://www.google.co.id (Diakses 20 Juli 
d. Metode Analisis

Untuk menganalisa data, penulis menggunakan content analysis (analisis isi) sebagaimana dikutip oleh Burhan Bungin mengatakan bahwa content analysis adalah suatu metodologi penelitian yang memanfaatkan seperangkat prosedur untuk menarik kesimpulan yang sahih dari sebuah buku atau dokumen. ${ }^{7}$

\section{B. Review Pustaka}

Penelitian terdahulu yang telah penulis temukan sampai sejauh ini, antara lain: Pertama, buku karya Balai Penelitian Jakarta dengan judul Pendidikan Agama Islam dalam Perspektif Multikulturalisme. Dalam buku ini menjelaskan kemungkinan integrasi kurikulum mata pelajaran PAI dengan PKn dalam membentuk masyarakat Indonesia yang berwawasan multikultural dengan tujuan memberi contoh bagi sekolah menengah terutama SMP dalam mengembangkan kurikulum PAI yang berwawasan multikultural tercermin dalam Standar Kompetensi (SK) dan Kompetensi Dasar (KD).

Kedua, buku karya Abdullah Aly dengan judul Pendidikan Islam Multikultural di Pesantren. Dalam buku ini menjelaskan pendidikan Islam multikultural di pesantren yang memfokuskan pada model pengembangan kurikulum di pondok pesantren modern Assalam Surakarta meliputi aspek perencanaan, implementasi dan evaluasi kurikulum PPMI Assalam Surakarta dalam perspektif multikultural.

Ketiga, Studi karya Syamsul Arifin dan Ahmad Barizi dengan judul Paradigma Pendidikan Berbasis Pluralisme dan Demokrasi; Rekonstruksi dan Akulturasi Tradisi Ikhtilaf dalam Islam. Studi ini menemukan 3 point: (1) tradisi ikhtilaf merupakan akar pluralisme dan demokrasi dalam Islam, (2) tradisi ikhtilaf merupakan konsep pendidikan demokrasi pendidikan Islam; dan (3) tradisi ikhtilaf merupakan tradisi penting yang perlu diaktualisasikan kembali untuk mengembangkan pendidikan demokrasi dalam pendidikan Islam. Studi ini mempertimbangkan dimensi pluralisme, 
ikhtilaf dan demokrasi sebagai bagian dari usaha menawarkan paradigma pendidikan Islam multikultural.

Keempat, Artikel Dede Rosyada dengan judul Pendidikan Multikultural di Indonesia Sebuah Pandangan Konsepsional. Artikel ini memberikan pandangan konsepsional tentang pendidikan multikultural di Indonesia terutama di sekolah harus mendesain proses pembelajaran, kurikulum dan evaluasi serta guru yang memiliki sikap dan perilaku multikultur sehingga bisa membina sikap para siswanya. Sedangkan dalam penelitian ini, penulis mencoba menguak tentang urgensi pendidikan multikultural untuk menumbuhkan nilai toleransi agama di Indonesia.

\section{Hasil (Pembahasan)}

\section{Pendidikan Multikultural dan Karakteristiknya}

Pendidikan multikultural dapat didefinisikan sebagai pendidikan untuk atau tentang keragaman kebudayaan dalam merespon perubahan demografis dan kultural lingkungan masyarakat tertentu bahkan dunia secara keseluruhan. Hal ini sejalan dengan pendapat Paulo Freire, ${ }^{8}$ pendidikan bukan merupakan menara gading yang berusaha menjauhi realitas sosial dan budaya. Pendidikan menurutnya, harus mampu menciptakan tatanan masyarakat yang hanya mengagungkan prestise sosial sebagai akibat kekayaan dan kemakmuran yang dialaminya.

Menurut L.H Ekstrand, ada 4 istilah yang sepadan dengan multikultural yaitu interethnic education, transcultural education, multiethnic education, dan cross-cultural education. ${ }^{9}$ Barry van Driel menambah istilah lain yakni human right education, intercultural dan inclusive education. Istilah di atas menurut Ekstrand dan Driel memiliki pengertian sama yakni konsep pendidikan yang memberi kesempatan yang setara kepada semua peserta didik tanpa melihat keadaan fisik, intelektual, sosiol, emosional, bahasa dan kondisi yang lain.

8Paulo Freire, Politik Pendidikan: Kebudayaan, Kekuasaan, dan Pembebasan, Terj. Agung Prihantoro (Yogyakarta: Pustaka Pelajar, 2002), h. 19

${ }^{9}$ L.H Ekstrand, Multicultural Education dalam Lawrence J.Saha, International Encyclopedia of the Sociology of Education, (New york: Pergamon, 1997), h. 345-346 
Secara etimologis, pendidikan multikultural terdiri dari dua kata yaitu kata "pendidikan" berarti proses pengembangan sikap dan tata laku seseorang dalam usaha mendewasakan manusia melalui upaya pengajaran, pelatihan, proses, perbuatan dan cara mendidik. Disisi lain, pendidikan adalah transfer of knowledge atau memindah ilmu pengetahuan. Sedangkan multikultural, multi berarti banyak, beragam dan aneka sedangkan kultural berasal dari kata culture yang mempunyai makna budaya, tradisi, kesopanan atau pemeliharaan.

Akar kata multikulturalisme adalah kebudayaan. Definisi kebudayaan menurut para ahli sangat beragam, namun dalam konteks ini kebudayaan dilihat dalam perspektif fungsinya sebagai pedoman bagi kehidupan manusia. Dalam konteks perspektif kebudayaan tersebut, maka multikulturalisme adalah ideologi yang dapat menjadi alat atau wahana untuk meningkatkan derajat manusia dan kemanusiannya. Multikulturalisme mengakui dan mengagungkan perbedaan dalam kesederajatan baik secara individual maupun secara kebudayaan. ${ }^{10}$

Secara terminologis, Calarry Sada mengutip tulisan Sleeter menjelaskan bahwa pendidikan multikultural memiliki empat makna (model), yakni: (1) pengajaran tentang keragaman budaya sebuah pendekatan asimilasi kultural, (2) pengajaran tentang berbagai pendekatan dalam tata hubungan sosial, (3) pengajaran untuk memajukan pluralisme tanpa membedakan strata sosial dalam masyarakat, dan (4) pengajaran tentang refleksi keragaman untuk meningkatkan pluralisme dan kesamaan. ${ }^{11}$

M. Ainul Yaqin memahami pendidikan multikultural sebagai strategi pendidikan yang diaplikasikan pada semua jenis mata pelajaran dengan cara menggunakan perbedaan-perbedaan kultural yang ada pada para siswa seperti perbedaan etnis, agama, bahasa, gender, klas sosial, ras, kemampuan dan umur agar proses belajar menjadi mudah. Pendidikan multikultural sekaligus melatih dan

\footnotetext{
${ }^{10}$ Rustam Ibrahim, Pendidikan Multikultural: Pengertian, Prinsip, dan Relevansinya dengan Tujuan Pendidikan Islam dalam jurnal Addin, vol.7, Februari 2013, h. 133

${ }^{11}$ Clarry Sada, Multicultural Education in Kalimantan Barat; an Overview, dalam Jurnal Multicultural Education in Indonesia and South East Asia, Edisi I, 2004, h. 85
} 
membangun karakter siswa agar mampu bersikap demokratis, humanis dan pluralis dalam lingkungan mereka. ${ }^{12}$

Mundzier Suparta dalam bukunya Islamic Multicultural Education, menyatakan definisi tentang pendidikan multicultural antara lain; (a) pendidikan multikultural adalah sebuah filosofi yang menekankan pada makna penting, legitimasi dan vitalitas keragaman etnik dan budaya dalam membentuk kehidupan individu, kelompok maupun bangsa. (b)pendidikan multikultural adalah menginstitusionalkan sebuah filosofi pluralisme budaya ke dalam sistem pendidikan yang didasarkan pada prinsipprinsip persamaan (equality), saling menghormati dan menerima, memahami dan adanya komitmen moral untuk sebuah keadilan social. (c) pendidikan multikultural adalah sebuah pendekatan pengajaran dan pembelajaran yang didasarkan atas nilainilai demokratis yang mendorong berkembangnya pluralisme budaya; dalam hampir seluruh bentuk komprehensifnya. (d) pendidikan multikultural merupakan reformasi sekolah yang komprehensif dan pendidikan dasar untuk semua anak didik yang menentang semua bentuk diskriminasi dan intruksi yang menindas dan hubungan antar personal di dalam kelas dan memberikan prinsip-prinsip demokratis keadilan sosial. ${ }^{13}$

Tujuan awal pendidikan multikultural yaitu membangun wacana pendidikan multikultural di kalangan guru, dosen, ahli pendidikan, pengambil kebijakan dalam dunia pendidikan dan mahasiswa dengan harapan mereka mempunyai wacana yang tidak hanya mampu membangun kecakapan dan keahlian siswa terhadap mata pelajaran yang diajarkan akan tetapi mampu menjadi transformator pendidikan multikultural yang mampu menanamkan nilai-nilai pluralisme, humanisme dan demokrasi secara langsung di sekolah kepada para peserta didiknya.

Di samping itu terdapat prinsip-prinsip pendidikan multikultural yaitu: (a) pemilihan materi pelajaran harus terbuka secara budaya didasarkan pada siswa.; (b) isi materi pelajaran yang dipilih harus mengandung perbedaan dan persamaan dalam lintas kelompok; (c) materi pelajaran yang dipilih harus sesuai dengan konteks waktu

\footnotetext{
${ }^{12}$ M.Ainul Yaqin, Pendidikan Multikultural; Cross-Cultural Understanding untuk Demokrasi dan Keadilan. h. 25

${ }^{13}$ Mundzier Suparta, Islamic Multicultural Education: Sebuah Refleksi atas pendidikan Agama Islam di Indonesia, (Jakarta: Al Ghazali Center, 2008), h. 37
} 
dan tempat; (d) pengajaran semua pelajaran harus menggambarkan dan dibangun berdasarkan pengalaman dan pengetahuan yang dibawa siswa ke kelas; (e) Pendidikan hendaknya memuat model belajar mengajar yang interaktif agar supaya mudah dipahami. ${ }^{14}$

Adapun karakteristik pendidikan multikultural ada 3, antara lain:

1. Berprinsip pada demokrasi, kesetaraan dan keadilan

Maksudnya semua anak (peserta didik) mempunyai hak yang sama untuk memperoleh pendidikan. Menurut Dede Rosyada, tidak hanya terbatas pada pemberian kesempatan untuk memperoleh pendidikan melainkan harus memperoleh perlakuan yang sama untuk memperoleh pelajaran di kelas. Dengan begitu, mereka memperoleh peluang untuk mencapai kompetensi keilmuwan dan ketrampilan sesuai minat mereka.

Dalam perspektif Islam, doktrin yang mengandung prinsip demokrasi, kesetaraan dan keadilan terdapat dalam al-Qur'an: QS. al-Syura (42):38; al-Hadid (57): 25; al-A'raf (7):181. Ketiga ayat tersebut memberi landasan moral bahwa setiap orang memiliki hak untuk memperoleh perlakuan adil baik dalam ucapan, sikap maupun perbuatan. Perlakuan adil di sini berkaitan dengan interaksi sosial antara muslim satu dengan muslim lainnya atau dengan non muslim. ${ }^{15}$ Doktrin Islam tentang prinsip demokrasi (almusyawarah), kesetaraan (al-musawah), dan keadilan (al-'adl) telah dipraktikkan Rasul untuk mengelola keragaman masyarakat di Madinah. Misal, Nabi membuat perjanjian tertulis yang dikenal dengan piagam Madinah. Piagam tersebut menetapkan seluruh penduduk Madinah memperoleh status sama dalam kehidupan.

2. Berorientasi Pada Kemanusiaan, Kebersamaan dan Kedamaian

Orientasi kemanusiaan dalam pendidikan multikultural relevan dengan konsep hablum min al-nas. Konsep ini menempatkan manusia pada 2 posisi yaitu ahsanu taqwim (mahluk terbaik) dan manusia harus tunduk pada hukum

\footnotetext{
${ }^{14}$ Ali Maksum dan Luluk Yunan Ruhendi, Paradigma pendidikan Universal di Era Modern dan Post-Modernisme (Yogyakarta: IRCiSod, 2004), h. 306

${ }^{15 `}$ Abd al-Latif Ibrahim, Tasamuh al-Gharb maa al-Muslimin Fi al-'Asr al-Hadir, (Riyad: Dar Ibn al-Jawzi, 1999, h. 45
} 
Allah. Kedua posisi tersebut melahirkan tentang pentingnya memelihara kelangsungan hidup manusia. Hubungan baik sesama manusia dalam perspektif Islam tidak hanya pada sesama ras, etnis, bahasa, budaya, dan agama melainkan dalam konteks yang lebih luas yaitu lain ras, etnis, bahasa, budaya dan agama sekaligus.

Kebersamaan dipahami sebagai sikap seseorang terhadap orang lain, atau sikap seseorang terhadap komunitas dan kelompok. Dalam perspektif Islam, kebersamaan ini relevan dengan konsep saling mengenal (ta'aruf) dan saling menolong ( $\left(a^{\prime} a w u n\right)$. kedua konsep ini terdapat dalam al-Qur'an surat alHujurat (49):13 dan al-Maidah (5): 2. Ini dijadikan landasan etik untuk membangun hubungan sosial yang baik dalam masyarakat majemuk di tengahtengah masyarakat.

Kedamaian hidup dalam suatu masyarakat dapat diwujudkan dengan cara menghindari terjadinya kekerasan, peperangan, dan tindakan mementingkan diri sendiri serta dengan cara menghadirkan keadilan. Artinya, pendidikan multikultural bertugas membentuk mindset peserta didik dalam membangun kehidupan sosial yang harmonis tanpa adanya permusuhan, konflik, kekerasan dan sikap mementingkan diri sendiri.

3. Mengembangkan Sikap Mengakui, Menerima dan Menghargai Keragaman

Dalam perspektif Islam, sikap menghargai keragaman yang harus diterima, diakui dan dihargai pararel dengan konsep al-ta'adudiyat (pluralisme) dan al-tanawwu' (keragaman) dalam Islam. Menurut Amir Husain, keberagaman merupakan fitrah dan sunatullah yang mengandung pelajaran penting berdialog dan bersikap toleransi (tasamuh) kepada pihak yang berbeda. Rasul mengenalkan ajaran Islam kepada masyarakat Mekah dan Madinah yang beragam suku dan agamanya seperti Kristen, Yahudi, Zoroaster. Beliau sering menggunakan metode dialog dengan mereka, sehingga Islam dapat hidup berdampingan secara damai dengan komunitas non-Muslim. Oleh karena itu, 
keragaman bukan menjadi faktor penghalang tetapi sebagai tantangan kreativitas dalam memperkenalkan Islam. ${ }^{16}$

Tabel I Karakteristik Pendidikan Multikultural

\begin{tabular}{|l|l|l|}
\hline \multicolumn{1}{|c|}{ Karakteristik } & $\begin{array}{c}\text { Nilai Multikultural Perspektif } \\
\text { Barat }\end{array}$ & \multicolumn{1}{|c|}{$\begin{array}{c}\text { Nilai Multikultural } \\
\text { Perspektif Islam }\end{array}$} \\
\hline $\begin{array}{l}\text { Berprinsip pada } \\
\text { demokrasi, } \\
\text { kesetaraan dan } \\
\text { keadilan }\end{array}$ & $\begin{array}{l}\text { Demokrasi, kesetaraan dan } \\
\text { keadilan. lawannya: } \\
\text { diskriminasi, hegemoni dan } \\
\text { dominasi. }\end{array}$ & $\begin{array}{l}\text { Al-musyawarah, al- } \\
\text { musawah, dan al-'adl }\end{array}$ \\
\hline $\begin{array}{l}\text { Berorientasi pada } \\
\text { kemanusiaan, } \\
\text { kebersamaan dan } \\
\text { kedamaian }\end{array}$ & $\begin{array}{l}\text { Kemanusiaan, kebersamaan dan } \\
\text { kedamaian. lawannya: } \\
\text { permusuhan, konflik, kekerasan, } \\
\text { dan mau menang sendiri. }\end{array}$ & $\begin{array}{l}\text { Hablum min al-nas, al- } \\
\text { ta'aruf, al-ta'awun, dan as- } \\
\text { salam }\end{array}$ \\
\hline $\begin{array}{l}\text { Mengembangkan } \\
\text { sikap mengakui, } \\
\text { menerima dan } \\
\text { menghargai } \\
\text { keragaman }\end{array}$ & $\begin{array}{l}\text { Toleransi, empati, simpati dan } \\
\text { solidaritas sosial. lawannya: } \\
\text { rasial, stereotip dan prejudis. }\end{array}$ & $\begin{array}{l}\text { Al-ta'adudiyat, al- } \\
\text { tanawwu', al-tasamuh, al- } \\
\text { rahmah, al-'afw, dan al- } \\
\text { ihsan }\end{array}$ \\
\hline
\end{tabular}

\section{Urgensi Pendidikan Multikultural}

a. Sebagai sarana alternatif pemecahan konflik

Penyelenggaraan pendidikan multikultural di dunia pendidikan diyakini dapat menjadi solusi nyata bagi konflik dan intoleransi yang terjadi di masyarakat. Dengan kata lain, pendidikan multikultural dapat menjadi sarana alternatif pemecahan konflik sosial budaya. Spektrum kultural masyarakat indonesia yang amat beragam menjadi tantangan bagi dunia pendidikan guna mengolah perbedaan tersebut menjadi suatu aset, bukan sumber perpecahan. Saat ini, pendidikan multikultural mempunyai dua tanggung jawab besar, yaitu: menyiapkan bangsa Indonesia untuk menghadapi arus budaya luar di era globalisasi dan menyatukan bangsa yang terdiri dari berbagai macam budaya.

Pendidikan kebangsaan dan ideologi telah banyak diberikan di perguruan tinggi, namun pendidikan multikultural belum diberikan dengan proporsi yang benar. Maka sekolah sebagai institusi pendidikan dapat

${ }^{16}$ Abdullah Aly, Pendidikan Islam Multikultural di Pesantren, (Yogyakarta: Pustaka Pelajar, 2011), h. 111-119 
mengembangkan pendidikan multikultural dengan model masing-masing sesuai asas otonomi pendidikan. Menurut penulis, pendidikan multikultural tersebut sebaiknya lebih ditekankan pada mata pelajaran agama, kebangsaan, dan moral. Pada dasarnya model pembelajaran seperti itu memang sudah ada. Namun, hal itu masih sekedar teori sedangkan dalam prakteknya belum terlaksana dengan baik.

Hal itu terlihat dengan munculnya konflik yang terjadi pada kehidupan berbangsa saat ini dimana pemahaman toleransi masih amat kurang. Hingga detik ini, jumlah siswa dan mahasiswa yang memahami makna budaya bangsa masih sangat sedikit. Padahal dalam konteks pendidikan multikultural, memahami makna dibalik realitas budaya suku bangsa merupakan hal yang esensial. Maka, penyelenggaraan pendidikan multikultural dapat dikatakan berhasil bila berbentuk pada diri siswa sikap hidup saling toleransi, tenggang rasa, tepo seliro, tidak bermusuhan dan tidak berkonflik yang disebabkan oleh perbedaan budaya, suku, bahasa, adat istiadat atau lainnya.

Menurut Stephen Hill, Direktur PBB bidang pendidikan, ilmu pengetahuan dan budaya, UNESCO untuk kawasan Indonesia, pendidikan multikultural dapat dikatakan berhasil bila prosesnya melibatkan semua elemen masyarakat. Secara konkret, pendidikan ini tidak hanya melibatkan guru atau pemerintah saja, namun seluruh elemen masyarakat. Hal itu dikarenakan adanya multi dimensi aspek kehidupan yang tercakup dalam pendidikan multikultural. Perubahan yang diharapkan dalam konteks pendidikan multikultural ini tidak terletak pada angka (kognitif) sebagaimana lazimnya penilaian keberhasilan pendidikan di negeri ini.

Namun, lebih dari itu yakni terciptanya kondisi yang nyaman, damai, toleran dalam kehidupan masyarakat, dan tidak selalu muncul konflik yang disebabkan oleh perbedaan budaya dan SARA. Bahkan, ada yang mengatakan bahwa hasil pendidikan multikultural tidak bisa diukur oleh waktu tertentu. Maka, di Indonesia sudah saatnya memberikan perhatian besar terhadap 
pendidikan multikultural. Secara tidak langsung, hal itu dapat memberikan solusi bagi permasalahan sosial dimasa mendatang. ${ }^{17}$

b. Supaya siswa tidak tercerabut dari akar budaya

Pendidikan multikultural juga signifikan dalam membina siswa agar tidak tercerabut dari akar budaya yang ia miliki sebelumnya, takala ia berhadapan dengan realitas sosial budaya di era globalisasi. Dalam era globalisasi saat ini, pertemuan antar budaya menjadi ancaman bagi anak didik. Untuk mensikapi realitas global tersebut, siswa hendaknya dibekali pengetahuan dan agama yang cukup, sehingga mereka memiliki kompetensi yang luas akan pengetahuan global, termasuk aspek kebudayaan.

Menurut Fuad Hasan, saat ini diperlukan langkah antisipatif terhadap tantangan globalisasi, utamanya dalam aspek kebudayaan. Sebab anak didik masa kini jauh berbeda dengan anak-anak seusianya di masa lalu. Beragam budaya yang ada di negeri ini, berbaur dengan budaya asing yang kian mudah diperoleh melalui beragam media, seperti televisi, internet,dll. Kemajuan IPTEK memperpendek jarak dan memudahkan persentuhan antar-budaya. Dan dimungkinkan terjadinya gesekan yang saling mempengaruhi budaya. Maka tantangan dalam dunia pendidikan kita saat ini sangat berat dan kompleks. Upaya antisipasi perlu dipikirkan secara serius, jika tidak maka generasi bangsa ini bisa kehilangan arah, tercerabut dari akar budayanya sendiri.

Menurut H.A.R. Tilaar, pendidikan multikultural telah menjadi suatu tuntutan yang tidak dapat ditawar-tawar dalam membangun Indonesia baru. Menurutnya, pendidikan multikultural memerlukan kajian yang mendalam mengenai konsep dan praksis pelaksanaannya baik secara ontologis, epistemologis maupun aksiologi. Ada baiknya apabila kita melihat pengalaman negara-negara yang telah mengaplikasikan pendidikan multikultural dalam masyarakat pluralistik serta terbuka di era globalisasi ini. Sebetulnya, realitas multikultural yang ada di indonesia merupakan kekayaan yang bisa menjadi 
model untuk mengembangkan kekuatan budaya. Maka, jelas bahwa kekayaan tersebut patut kita jaga dan lestarikan.

c. Sebagai landasan pengembangan kurikulum nasional

Dalam melakukan pengembangan kurikulum sebagai titik tolak dalam proses belajar mengajar, atau guna memberikan sejumlah materi yang harus dikuasai oleh siswa dengan ukuran tertentu, pendidikan multikultural sebagai landasan pengembangan kurikulum menjadi sangat penting. Pengembangan kurikulum masa depan yang berdasarkan pendekatan multikultural dapat dilakukan berdasarkan langkah-langkah sebagai berikut:

1) Mengubah filosofi kurikulum saat ini pada yang lebih sesuai dengan tujuan, misi, dan fungsi setiap jenjang pendidikan.

2) Teori kurikulum (curriculum content), harus berubah dari teori yang mengartikan konten sebagai aspek substantif ke pengertian yang mencakup nilai moral, proses dan keterampilan (skill) yang harus dimiliki generasi muda.

3) Teori belajar yang digunakan dalam kurikulum masa depan yang memperhatikan keragaman social, budaya, ekonomi, dan politik.

4) Proses belajar yang dikembangan untuk siswa harus berdasarkan proses yang memiliki daya saing secara kompetitif dengan kelompok lain.

5) Evaluasi yang digunakan meliputi keseluruhan aspek kemampuan dan kepribadian peserta didik, sesuai dengan konten yang dikembangkan.

Alat evaluasi yang digunakan harus beragam sesuai dengan sifat, tujuan dan informasi yang ingin dikumpulkan. Indonesia sebagai negara majemuk perlu menyusun konsep pendidikan multikultural sehingga menjadi pegangan untuk memperkuat indentitas nasional. Dengan cara ini diharapkan generasi muda setidaknya memiliki identitas nasional, sehingga mereka tidak mudah dipecah belah, dan mampu bersaing di era globalisasi.

Negara yang berpenduduk majemuk seperti Amerika,Australia,dan Kanada telah mengajarkan pendidikan multibudaya pada sekolah formal dan informal. Menurut Hamid Hasan, masyarakat Indonesia memiliki keragaman social budaya, aspirasi politik dan kemampuan politik. Keragaman ini pula 
menjadi pengaruh terhadap kemampuan guru dalam melaksanakan kurikukulum, kemampuan sekolah dalam menyediakan pengalaman belajar, kemampuan siswa dalam proses belajar, serta mengolah informasi menjadi sesuatu yang dapat di terjemahkan sebagai hasil belajar.

Para ahli pendidikan menyadari bahwa kebudayaan adalah salah satu landasan pengembangan kurikulum. Ki Hajar Dewantara menyatakan kebudayaan merupakan faktor penting sebagai akar pendidikan suatu bangsa. Kebudayaan merupakan totalitas cara manusia hidup dan mengembangkan pola kehidupannya sehingga ia tidak saja menjadi landasan dimana kurikulum dikembangkan tetapi menjadi target hasil pengembangan kurikulum. Dalam buku yang berjudul Sociocutural Origins of Achievment, Maehr (1974) mengatakan keterkaitan kebudayaan dan bahasa, kebudayaan dan persepsi, kebudayaan dan kognisi, kebudayan dan keinginan berprestasi, serta kebudayaan motivasi berprestasi, merupakan factor-faktor yang berpengaruh terhadap siswa.

Studi Webb (1990) dan Burnet (1994) menunjukkan bahwa proses belajar siswa yang dikembangkan melalui budaya menunjukkan hasil yang lebih baik. Oleh karena itu, sudah saatnya untuk memperhitungkan faktor kebudayaan sebagai landasan dalam menentukan komponen tujuan, materi, proses, evaluasi, kegiatan belajar siswa. Konsekuensinya pengembang kurikulum ditingkat pusat, daerah, dan sekolah harus memanfaatkan kebudayaan sebagai landasan kurikulum secara lebih sistematis.

Indonesia adalah negara kaya budaya seperti dinyatakan dalam motto nasional Bhineka Tunggal Ika. Oleh sebab itu proses pengembangan kurikulum harus memperhatikan keragaman kebudayaan yang ada, seharusnya di Indonesia harusnya memakai pendekatan multicultural sebagai pengembang kurikulum. Menurut UU nomor 22 tahun 1999 dan No. 32/2004 tentang otonomi daerah tidak akan secara langsung menjadikan pendidikan multicultural berlaku dalam pengembangan kurikulum di Indonesia.

d. Menuju masyarakat Indonesia yang multikultural 
Dalam masyarakat multikultural ditegaskan corak masyarakat Indonesia yang beragam bukan hanya dimaksudkan pada keanekaragaman suku bangsa, melainkan juga keanekaragaman budaya yang ada pada masyarakat. Eksistensi keragaman budaya tersebut tampak dalam sikap saling menghargai, menghormati, toleransi antara budaya satu dengan lainnya. Dalam konteks ini ditegaskan, bahwa perbedaan bukan menjadi penghalang untuk bersatu mewujudkan cita-cita dalam kehidupan berbangsa dan bernegara sebagimana termaktub dalam UUD 1945 dan Pancasila.

Acuan utama bagi terwujudnya masyarakat Indonesia yang multikultural adalah multikulturalisme, yaitu sebuah ideologi yang mengakui dan mengagungkan perbedaan dalam kesederajatan baik secara individual maupun secara kebudayaan. Model multikulturalisme ini sebenarnya telah digunakan oleh para pendiri bangsa (founding fathers) dalam mendesain kebudayaan bangsa, sebagaimana yang terungkap dalam penjelasaan Pasal 32 UUD 1945, yang berbunyi: "kebudayaan bangsa (Indonesia) adalah puncak kebudayaan di daerah."

Upaya membangun Indonesia yang multikultural hanya mungkin dapat terwujud bila: Pertama, konsep multikulturalisme dipahami urgensinya oleh bangsa Indonesia dan menjadikannya pedoman hidup. Kedua, adanya kesamaan pemahaman mengenai makna multikulturalisme bagi kehidupan berbangsa. Ketiga, kajian multikulturalisme meliputi berbagai permasalahan, yaitu politik dan demokrasi, keadilan dan penegakan hukum, kesempatan kerja dan berusaha, HAM, hak budaya prinsip-prinsip etika dan moral.

Multikulturalisme bukan hanya sebuah wacana tetapi sebuah ideologi yang harus diperjuangkan. Karena, multikulturalisme sangat di butuhkan sebagai landasan bagi tegaknya demokrasi, HAM, dan kesejahteraan hidup suatu masyarakat yang majemuk (plural society). Multikulturalisme bukan sebuah ideologi yang berdiri sendiri tetapi membutuhkan konsep lain yang dijadikan acuan untuk memahami dalam kehidupan bermasyarakat.

Berbagai konsep yang relevan dengan multikulturalisme antara lain adalah demokrasi, keadilan dan hukum, nilai-nilai budaya dan etos, kebersamaan dalam perbedaan yang sederajat, suku bangsa, kesukubangsaan, kebudayaan suku 
bangsa, keyakinan keagamaan, HAM, hak budaya komuniti, dan konsep-konsep lainnya yang relevan. Masalah yang dihadapi berkenaan dengan upaya menuju masyarakat Indonesia yang multikultural sangatlah kompleks.

Dalam kesempatan ini, ada baiknya bila semua melakukan instrospeksi mengenai kesiapan tersebut. Pertama, kita mempersiapkan diri melalui berbagai kegiatan diskusi, seminar, atau lokakarya untuk menambah ilmu pengetahuan, dan mempertajam metodologi yang relevan mengenai masyarakat multikultural. Kedua, secara metodologi, berbagai kajian etnografi tradisional pada penelitian mahasiswa untuk skripsi sebaiknya ditinjau kembali untuk diubah sesuai perkembangan antropologi yang ada. Ketiga, ada baiknya para ahli secara bersama-sama melihat, mengembangkan dan menciptakan model penerapan multikulturalisme dalam masyarakat. Sehingga, upaya menuju masyarakat Indonesia yang multikultural itu dapat dengan secara cepat dan efektif berhasil diwujudkan.

\section{Implementasi Pendidikan Multikultural di Indonesia Untuk Menumbuhkan Nilai Toleransi Agama}

Hingga saat ini bangsa Indonesia terus dihimpit oleh berbagai problem, mulai dari problem politik, budaya, ekonomi, hukum hingga pendidikan. Berbagai kekerasan yang berbau SARA di negara ini sangat memprihatinkan. Misalnya, penistaan agama, terorisme, pelecehan seksual, KDRT, trafficking, konflik antar agama dan aliran, dan lain-lain. Di satu sisi multikultur menjadi sumber perekat keragaman etnis, tetapi disisi lain berpotensi konflik yang sewaktu-waktu meletus.

Sampai saat ini pendidikan multikultural memang masih sebatas wacana. Praktek pendidikan multikultural di Indonesia nampaknya memerlukan waktu panjang, walaupun ditinjau dari keragaman budaya sudah mendukung. Hal itu disebabkan oleh perjalanan panjang histori penyelenggaraan pendidikan yang banyak dilatarbelakangi oleh primordialisme. Misalnya pendirian lembaga pendidikan berdasar latar belakang agama, daerah, perorangan maupun kelompok. 
Oleh karena itu, praktek pendidikan multikultural di Indonesia dapat dilaksanakan secara fleksibel dengan mengutamakan prinsip-prinsip dasar multikultural yakni menuntut peran pendidik (guru, dosen, ustad dsb) untuk mampu tampil profesional dengan mengintegrasikan multikulturalisme dalam pendidikan; memilih strategi yang relevan; memperkuat pendidikan karakter di sekolah; dan memberikan materi yang kontekstual untuk menumbuhkan toleransi agama di sekolah.

a. Mengintegrasikan Multikulturalisme dalam Pendidikan

Ada tiga istilah yang sering digunakan untuk menggambarkan keberagaman, yaitu keberagaman agama, ras, bahasa dan budaya atau dikenal dengan istilah (plurality), (diversity), dan (multicultural). Menurut Sonia, pendidikan multikultural harus melekat pada kurikulum dan strategi pengajaran termasuk interaksi antara guru, murid dan keluarga serta keseluruhan suasana belajar mengajar. Karena jenis pendidikan ini merupakan pedagogi kritis, reflektif dan berbasis aksi perubahan dalam masyarakat. Konsekuensinya, pendidikan multikultural mampu mengembangkan prinsip demokrasi dalam berkeadilan sosial. ${ }^{18}$

Cara mengintegrasikannya lewat mata pelajaran PKN dan PAI, kita harus mengetahui ruang lingkup mata pelajaran tersebut. Jika ruang lingkup PKN adalah persatuan dan kesatuan bangsa meliputi hidup rukun, cinta lingkungan, sumpah pemuda, keutuhan NKRI, partisipasi dalam pembelaan negara, sikap positif, keterbukaan, dan jaminan keadilan. Adapun PAI diharapkan menghasilkan manusia yang jujur, adil, berbudi pekerti, etis, saling menghargai, disiplin, harmonis dan produktif baik personal maupun sosial.19

Metode yang ditempuh dalam upaya mengintegrasikan PAI dan PKn, yaitu: pertama, mempertimbangkan PAI dan PKn mempunyai titik kesamaan dalam tujuan dan ruang lingkup pembelajaran. Keduanya bekerja di wilayah pendidikan karakter yang mempunyai dimensi individual dan sosial. Maksudnya, sisi privat menekankan pada spiritualitas dan religiusitas anak

\footnotetext{
${ }^{18}$ Nieto Sonia, Languae, Culture and Teaching, (Mahwah, NJ: Lawrence Earlbaum, 2002), 29

${ }^{19}$ Balai Penelitian Jakarta, Pendidikan Agama Islam dalam Perspektif Multikulturalisme, (Jakarta: Balai Litbang, 2009), h. 11-12
} 
didik. Guru memberikan dasar-dasar keimanan yang diimplementasikan dalam ritual seperti shalat, puasa, zakat dan haji. Sedangkan sisi publik menekankan pada ajaran agama yang dapat membentuk kesalehan sosial. Sedang PKn, mencetak generasi yang berperadaban dan demokratis dengan tetap mengedepankan prinsip toleransi.

Kedua, mengembangkan mata pelajaran PAI dan PKn sebagai kecakapan hidup (life skill). Konsep kecakapan ada dua, yakni personal dan sosial. Kecakapan personal meliputi mengenal diri yaitu kesadaran penghayatan kepada Tuhan, kesadaran sebagai warga negara, serta sadar akan kelebihan dan kekurangan yang dimiliki. Sementara kecakapan sosial adalah kecakapan bekerjasama dan komunikasi sosial antar anggota masyarakat. Dengan begitu, anak didik akan menjadi manusia bertakwa yang membawa pada kesalehan individual dan sosial.

Tabel 2. PAI-Pkn Terintegrasi Sebagai Pendidikan Kecakapan Hidup

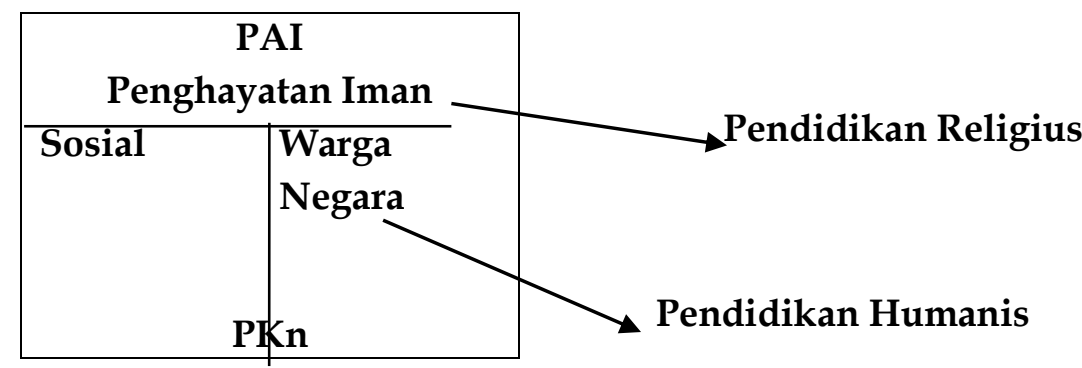

b. Metode dan Strategi Pembelajaran yang Relevan

Ketepatan dalam memilih metode pembelajaran merupakan salah satu faktor penting dalam membangkitkan motivasi dan semangat belajar peserta didik. Adapun metode mengajar yang kita kenal dalam dunia pendidikan adalah metode ceramah, diskusi, eksperimen, demonstrasi, pemberian tugas, drill, kerja kelompok, tanya jawab, simulasi, karya wisata, dsb.

Menurut James A.Banks adalah strategi-strategi pembelajaran yang dapat memfasilitasi para siswa untuk belajar, bisa mengeksplorasi sumber-sumber informasi, bisa melakukan interpretasi dan membuat kesimpulan-kesimpulan 
yang mereka perlukan dalam mengembangkan sikap dan perilakunya yang sesuai dengan paradigma masyarakat multikultur yang demokratis, berkeadilan dan mengharhagai HAM. Oleh sebab itu, dalam membina dan mengembangkan sikap multikultur, guru harus melibatkan siswa dalam proses mencari informasi, membahas berbagai persoalan yang terkait dengan informasi-informasi tersebut, serta merefleksi nilai-nilai yang mereka peroleh dalam proses pembelajarannya itu.

Proses pembelajaran harus dikembangkan secara dinamis dan kombinatif antara teknik yang berpusat pada guru dengan teknik-teknik yang melibatkan siswa dalam proses belajar, sehingga sikap afeksinya tumbuh dan berkembang dalam jiwa para siswa. Pengajaran yang berpusat pada guru merupakan salah satu bentuk exposition teaching (ceramah) layak untuk digunakan menyampaikan berbagai informasi dalam waktu yang sangat terbatas.

Kemudian model ceramah lain adalah socratic teaching, yakni ceramah atau ekspose yang diawali dengan pertanyaan, lalu ada jawaban, dan terus dikembangkan pertanyaan berbasis jawaban siswa dan seterusnya sehingga terjadi interaksi antara guru dengan siswa. Dan model lainnya yaitu demonstrasi yakni guru atau seseorang mendemontrasikan informasi di depan kelas, sebagai penguatan visual terhadap informasi yang disampaikan, atau sebagai contoh untuk ditiru oleh siswa melalui latihan-latihan yang harus mereka kembangkan. ${ }^{20}$

Begitu banyak wacana tentang strategi pelibatan siswa dalam proses pembelajaran. Kenneth D.Moore menyebutnya dengan student centered instruction (pembelajaran berpusat pada siswa), salah satunya adalah diskusi, yang bisa dibentuk dalam berbagai strategi, dari small group discussion sampai seminar. Untuk pengembangan afektif sangat efektif menggunakan metode diskusi, karena siswa terlibat benar dengan masalah yang menjadi fokus pembahasan. Jika membentuk diskusi kelompok, sebaiknya terdiri dari siswa yang berbeda latar belakang seperti kemampuan, suku, budaya dan agama dengan tujuan mereka mampu

20 Dede Rosyada,Pendidikan Multikultural di Indonesia Sebuah Pandangan Konsepsional dalam Sosio Didaktika: Vol.1, No.1 Mei 2014, h. 6 
memahami dan menghargai kekurangan teman yang lain sehingga munculah rasa toleransi.

Menurut Glasser, ada empat hal yang harus dikuasai guru, yaitu: (a) menguasai bahan pelajaran; (b) kemampuan mendiagnose tingkah laku siswa; (c) kemampuan melakukan proses pengajaran; (d) kemampuan mengukur hasil belajar siswa. Maka kompetensi guru dikelompokkan menjadi tiga bidang: kognitif/intelektual, sikap dan performance/perilaku. Selain dalam kompetensi guru dan metodenya, nilai-nilai multikultural juga ditemukan pada tempat pembelajaran. Guru dengan bijak mengalihkan tempat pembelajaran di luar kelas seperti taman, laboratorium, perpustakaan, masjid, atau tempat-tempat yang alami dipilih berdasarkan kebutuhan fisik maupun psikologis. Hal ini menunjukkan bahwa para guru memiliki sikap demokratis yang berimplikasi pada terciptanya suasana pembelajaran yang menyenangkan.

Sikap demokratis juga ditunjukkan dalam interaksi antara guru dan siswa dalam proses pembelajaran. Sikap tersebut terlihat dari kesempatan yang diberikan kepada siswa untuk membentuk kelompok, mengajukan pertanyaan, dan mempresentasikan materi kepada sesama peserta didik. Kesempatan ini diberikan secara adil kepada seluruh peserta didik tanpa melihat asal usul daerah mereka. Hal ini menunjukkan adanya pengakuan para guru terhadap keberadaan dan kemampuan para siswa yang merupakan ciri pendidikan multikultural. Pengakuan ini juga berdampak positif bagi terciptanya rasa percaya diri pada peserta didik. Oleh karena itu, siswa cenderung menyukai guru yang komunikatif, demokratis, dan adil pada saat proses pembelajaran baik di dalam kelas maupun luar kelas. ${ }^{21}$

Pada akhirnya, kompetensi-kompetensi kognitif, afektif dan psikomotorik bisa dicapai dengan berbagai strategi yang melibatkan siswa dalam belajar, baik melalui discovery learning, group work, cooperative learning, dll yang dapat dikembangkan guru. Siswa memiliki tujuan yang hendak dicapai, guru memfasilitasi, dan semua saling membantu. Mereka tidak berkompetisi satu sama lain, tapi mereka berkompetisi dengan mereka sendiri. Itulah hakikat dari salah 
satu gagasan besar dalam reformasi pendidikan di Indonesia yang memiliki keinginan untuk mengembangkan proses pembelajaran dengan prinsip baru learning to do, learning to be, learning to learn, dan learning to live together.

c. Penguatan Pendidikan Karakter di Sekolah

Arus globalisasi telah merubah wajah dunia semakin indah dan berkembang. Globalisasi memberi dampak positif antara lain, berkembangnya teknologi diberbagai bidang, meningkatnya sarana dan prasarana dan lain sebagainya. Adapun dampak negatifnya, menurut Maragustam adalah melahirkan umat manusia yang tuna karakter (berkarakter baik-lemah, jelek-kuat, jelek-lemah). Oleh karena itu, dibutuhkan penggalakan pendidikan karakter terhadap generasi bangsa agar dapat mengatasi dampak negatif dari globalisasi. Ada tiga pilar dalam pendidikan karakter: pilar keluarga, lingkungan dan sekolah22, bila implementasi pendidikan karakter ditopang oleh pilar yang kuat maka karakter tidak mudah hilang. Pembentukan karakter tersebut tidak akan berhasil selama tidak ada kesinambungan antar ketiga pilar tersebut.

Lingkungan sekolah dapat dijadikan sebagai tempat yang baik bagi pendidikan karakter siswa. Pendidikan karakter melalui sekolah, tidak semata-mata belajar mengenai pengetahuan (sains) saja, tapi lebih dari itu yaitu penanaman moral, nilai-nilai etika, budi pekerti luhur, dan lain sebagainya. Pemberian penghargaan kepada yang berprestasi dan hukuman kepada yang melanggar, dapat menyuburkan nilai-nilai yang baik dan mencegah berlakunya nilai-nilai yang buruk.

Pendidikan adalah usaha sadar dan terencana untuk mewujudkan suasana belajar dan proses pembelajaran agar peserta didik secara aktif mengembangkan potensi dirinya untuk memiliki kekuatan spiritual keagamaan, pengendalian diri, kepribadian, kecerdasan, akhlak mulia, serta keterampilan yang diperlukan dirinya, masyarakat, bangsa dan negara. Adapun karakter adalah watak, tabiat, akhlak, atau kepribadian seseorang yang terbentuk dari hasil internalisasi berbagai kebajikan (virtues) yang diyakini sebagai landasan untuk cara pandang, berpikir, bersikap,

${ }^{22}$ Abdul Majid dan Dian Andayani, Pendidikan Karakter Prespektif Islam, (Bandung; Remaja Rosdakarya, 2011), h. 155-157 
dan bertindak. Karakter juga merupakan sifat utama yang terukir, baik pikiran, sikap, prilaku maupun tindakan yang melekat dan menyatu kuat pada diri seseorang, yang membedakannya dengan orang lain. Karena karakter tersebut sebuah ukiran dalam jiwa, maka ia sulit untuk diubah. ${ }^{23}$

Nilai adalah segala sesuatu yang dianggap bermakna bagi kehidupan seseorang yang dipertimbangkan berdasarkan kualitas benar-salah, baik-buruk, indah tidak indah, yang orientasinya bersifat antroposentris atau theosentris. ${ }^{24}$ Artinya nilai itu dianggap penting atau baik apabila sesuai dengan kebutuhan masyarakat. Adapun nilai-nilai yang terdapat pada karakter yaitu: a) religius, b) jujur, c) toleransi, d)disiplin, e) kerja keras, f) kreatif, g) mandiri, h)demokratis, i) rasa ingin tahu, j)semangat kebangsaan, k)cinta tanah air, l)menghargai prestasi, m) bersahabat/komunikatif, n) cinta damai, o) gemar membaca.

Baru-baru ini menteri Pendidikan dan Kebudayaan melakukan berbagai upaya untuk meningkatkan akses kualitas layanan pendidikan dan penguatan karakter melalui kebudayaan. Kebudayaan menjadi payung utama dalam upaya merevolusi karakter bangsa karena jika siswa mengenal budayanya sendiri maka akan tumbuh sikap nasionalisme dan cinta tanah air. Terlebih kebudayaan telah diajarkan sejak pendidikan dasar (SD/SMP) hingga menengah (SMA) dan perguruan tinggi, namun mirisnya banyak generasi muda saat ini yang tidak mengenal budayanya sendiri. Maka dari itu, pendidikan karakter mempunyai peran yang besar untuk mengenalkan budaya dan nasionalisme sejak dini.

\section{d. Menumbuhkan Nilai Toleransi Agama}

Indonesia adalah negara yang majemuk, baik dari aspek sosial, budaya, suku bangsa, ras, aliran dan agama. Oleh karenanya, masyarakat Indonesia disebut sebagai masyarakat multikultural. Menghadapi kondisi ini, bangsa Indonesia dituntut untuk mampu merekonstruksi kebudayaan nasional yang dapat menjadi

${ }^{23}$ Maimunah, Pembentukan Karakter Peduli Lingkungan Pada Peserta Didik di Madrasah Aliyah Serambi Mekkah Sumatera Barat dalam Proceeding International The Dynamic Of Malay Islamic World In Responding To Contemporary Global Issues UIN Raden Fatah Palembang, 2-3 Des 2016, h. 247

${ }^{24}$ Jamal Ma'mur Asmani, Buku Panduan Internalisasi Pendidikan Karakter di Sekolah (Yogyakarta: Diva Press, 2011), h. 43 
perekat (integrating force) terhadap keragaman dan heterogenitas sosial budaya, terlebih dalam kehidupan beragama.

Menyinggung keberadaan agama di negeri ini juga beragam antara lain: Islam, Hindu, Budha, Kristen, Konghucu. Agama dan tradisi dalam sejarah kehidupan umat manusia ibarat dua sisi mata uang yang tak dapat dipisahkan. Masing-masing mempunyai hak yang sama termasuk mempertahankan tradisi dan identitasnya. Cara yang paling tepat adalah melalui jalur pendidikan, ia merupakan alat paling efektif untuk meneruskan, melanggengkan, melestarikan dan mempertahankan tradisi dari satu generasi ke generasi berikutnya.

Akhir-akhir ini, masih ada konflik yang dikesankan atas nama agama terjadi di sejumlah daerah. Pada dasarnya, konflik tersebut sama sekali tak berlatar belakang agama. Hanya ada pihak-pihak yang berupaya mengadudomba yang membuat konflik tersebut terkesan karena perbedaan agama. Meski jumlahnya tidak banyak, konflik itu tetap harus diredam dengan mengoptimalkan peran Forum Kerukunan Umat Beragama (FKUB) di setiap daerah. ${ }^{25}$

Nilai-nilai toleransi dalam kaitannya dengan pendidikan agama idealnya mampu mencegah semangat ekslusivisme. Pelajaran agama yang bersifat doktriner, eksklusif dan kurang menyentuh aspek moralitas sudah tentu tidak relevan dengan masyarakat Indonesia yang multikultur. Selain hanya cenderung penekananya pada aspek kongnitif saja, juga dapat menimbulkan penafsiran negatif dari umat lain. Oleh karena itu perlu ada kesadaran siswa dalam bersikap toleransi di sekolah melalui pendidikan agama.

Terjadinya konflik sosial yang mengatasnamakan agama bukanlah doktrin agama, karena setiap agama mengajarkan kepada umatnya sikap toleransi dan menghormati sesama. Sehingga kita sebagai umat beragama diharapkan bisa membangun sebuah tradisi wacana keagamaan yang menghargai keberadaan agama lain, dan bisa menghadirkan wacana agama yang toleransi serta transformatif. ${ }^{26}$ Seperti ditegaskan dalam QS. Al-Kafirun:1-6:

${ }^{25}$ http://nasional.kompas.com/read/2016/12/30/22134081, Diakses 20 Agustus 2017

${ }^{26}$ Nurkholis Majid, Pluralitas Agama: Kerukunan dalam keagamaaan; (Jakarta: Kompas Nusantara, 2001), h. 38-39 
Katakanlah: "Hai orang-orang kafir, aku tidak akan menyembah apa yang kamu sembah dan kamu bukan penyembah Tuhan yang aku sembah. Dan aku tidak pernah menjadi penyembah apa yang kamu sembah, dan kamu tidak pernah (pula) menjadi penyembah Tuhan yang aku sembah. untukmu agamamu, dan untukkulah, agamaku."

Ayat diatas menunjukan bahwa Allah Swt telah memerintahkan kepada umatnya agar selalu dapat bertoleransi dalam masalah agama, Toleransi disini adalah dengan menganut agama masing-masing dan menghargai eksistensi agama lain. Dalam sejarah Islam tidak pernah memaksakan keyakinanya kepada orang lain.

Peranan penting dari pendidikan multikultural adalah menumbuhkan nilainilai toleransi antar umat beragama. Pendidikan ini bisa dimulai dari dasar SD sampai SMA dengan mengajarkan materi-materi agama, kebangsaan, seni budaya, dan pengetahuan umum yang komprehensif tidak hanya bersifat kognitif tetapi juga transformasi nilai dan etik kepada peserta didik. Nilai-nilai itu ada yang dibakukan menjadi kurikulum wajib, dan adapula yang diserahkan kepada pendidik sendiri untuk melakukan inovasi selama tidak bertentangan dengan tujuan pendidikan itu sendiri.

Menurut penulis, pendidikan saat ini cukup memprihatinkan, karena banyak peserta didik yang tidak mengenal kebudayaan bangsa ini. Bahkan kesenian seperti lagu daerah, bahasa, adat istiadat, dan norma kesopanan mulai terkikis seiring perkembangan teknologi informasi. Maka dari itu diperlukan pengembangan pendidikan yang berwawasan multikultural sebagai upaya untuk mengatasi konflik dan permasalahan yang terjadi saat ini.

Kunci keberhasilan pendidikan agama terletak pada sejauh mana kedalaman transfer nilai dapat dilalui anak didik setiap hari. Jika siswa hanya dapat menguasai materi saja, tetapi tidak mampu mengaplikasikan nilai-nilai yang terkandung dalam pelajaran agama tersebut dalam kehidupan sehari-hari maka berakibat fatal. Misal, para siswa saat ini hafal dalil tentang larangan bertengkar, bermusuhan, saling menyakiti dan saling membunuh, tetapi mereka belum bisa merealisasikan ajaran tersebut dalam kehidupan sehari-hari, dengan masih maraknya tawuran antar pelajar dan banyak siswa yang terlibat dalam tindak kekerasan/amoral. 
Guru merupakan faktor penting dalam mengimplementasikan nilai-nilai keberagaman yang inklusif dan moderat di sekolah. Guru mempunyai posisi penting dalam pendidikan multikultural karena dia merupakan salah satu icon pendidikan ini. Apabila guru mempunyai paradigma pemahaman keberagaman inklusif dan moderat, maka dia mampu mengajarkan dan mengimplementasikan nilai-nilai keberagaman tersebut terhadap siswa sekolah.

Peran guru dalam hal ini meliputi: pertama, seorang guru harus mampu bersikap demokratis, artinya dalam segala tingkah lakunya, baik perkataan maupun sikapnya tidak diskriminatif (bersikap tidak adil/menyinggung) murid-murid yang menganut agama yang berbeda dengannya. Ketika seorang guru sejarah menjelaskan tentang perang salib yang melibatkan kelompok Kristen dan Islam, maka dia harus mampu bersikap tidak memihak salah satu kelompok yang terlibat meskipun agama yang dianut sama dengan salah satu kelompok tersebut. Apabila memihak salah satu kelompok, tentu penjelasannya akan menjadi subjektif. Akibatnnya, penjelasannya tidak saja melukai hati murid yang agamanya beda, tapi juga menimbulkan permusuhan dalam diri murid. ${ }^{27}$

Kedua, guru seharusnya mempunyai kepedulian yang tinggi terhadap kejadiankejadian tertentu yang ada hubungannya dengan agama. Contoh, ketika terjadi pemboman terhadap sebuah kafe di Bali (2003), maka guru yang berwawasan multikultural harus mampu menjelaskan keprihatinannya terhadap peristiwa tersebut. Kemudian menjelaskan bahwa kejadian tersebut jangan sampai terjadi, karena semua agama baik Islam, Kristen, Katolik, Budha, Hindu, Konghucu dll jelas dikatakan bahwa segala macam bentuk kekerasan dalam memecahkan masalah dilarang. Kekerasan hanya akan menimbulkan masalah baru.

Berkaitan dengan hal itu, seorang guru harus menjelaskan bahwa inti dari ajaran agama adalah menciptakan kedamaian dan kesejahteraan bagi seluruh umat manusia. Pemboman, invasi militer, perang (segala bentuk kekerasan) adalah sesuatu yang dilarang oleh agama. Dialog dan musyawarah adalah cara

${ }^{27}$ M.Ainul Yaqin, Pendidikan Multikultural; Cross-Cultural Understanding untuk Demokrasi dan Keadilan. h. 61-63 
penyelesaian segala bentuk masalah yang sangat dianjurkan semua agama dan kepercayaan yang ada.

Peran sekolah juga sangat penting dalam membangun lingkungan pendidikan yang pluralis dan toleran terhadap semua pemeluk agama. Untuk itu sebaiknya sekolah memperhatikan langkah-langkah berikut: pertama, sekolah sebaiknya menerapkan undang-undang lokal. Dalam undang-undang sekolah tersebut, salah satu poin penting yang tercantum adalah larangan terhadap segala bentuk diskriminasi agama di sekolah. Dengan diterapkan peraturan ini diharapkan semua unsur yang ada seperti guru, kepala sekolah, pegawai administrasi, dan murid dapat belajar untuk selalu menghargai orang lain yang berbeda agama di lingkungan mereka.

Kedua, untuk membangun saling pengertian sejak dini antar siswa yang mempunyai keyakinan agama berbeda maka sekolah harus berperan aktif menggalakkan dialog keagamaan yang berada dalam bimbingan guru-guru dalam sekolah tersebut. Guru agama sebagai ujung tombak pendidikan agama dari TK sampai perguruan tinggi, selama ini nyaris tidak tersentuh. Diskusi merupakan salah satu upaya efektif agar siswa dapat membiasakan diri melakukan dialog dengan penganut agama yang berbeda.

Ketiga, kurikulum dan buku-buku pelajaran yang dipakai di sekolah. Kurikulum pendidikan yang multikultural merupakan syarat utama yang tidak bisa ditolak dalam menerapkan strategi pendidikan ini. Pada intinya, kurikulum pendidikan multikultural adalah kurikulum yang memuat nilai-nilai pluralisme dan toleransi keberagaman. Begitu juga buku-buku agama yang dipakai disekolah, sebaiknya buku-buku yang dapat membangun wacana peserta didik tentang keberagaman yang inklusif dan moderat.

\section{Kesimpulan}

Berdasarkan hasil pengamatan secara kepustakaan, maka penulis mengambil beberapa kesimpulan sebagai berikut:

1. Pendidikan multikultural menurut M.Ainul Yaqin merupakan strategi pendidikan yang diaplikasikan pada semua jenis mata pelajaran dengan cara menggunakan 
perbedaan-perbedaan kultural yang ada pada para siswa seperti perbedaan etnis, agama, bahasa, gender, klas sosial, ras, kemampuan dan umur agar proses belajar menjadi mudah.

2. Urgensi pendidikan multikultural di Indonesia antara lain: a) Sebagai sarana alternatif pemecahan konflik; b) Supaya siswa tidak tercerabut dari akar budaya; c) Sebagai landasan pengembangan kurikulum nasional; d) Menuju masyarakat Indonesia yang multikultural.

3. Implementasi pendidikan multikultural di Indonesia untuk menumbuhkan toleransi agama melalui: a)Mengintegrasikan multikulturalisme dalam pendidikan melalui mata pelajaran Agama dan PKn; b)Metode dan strategi pembelajaran yang relevan misalnya, kompetensi kognitif, afektif dan psikomotorik bisa dicapai dengan berbagai strategi pembelajaran; c)Penguatan pendidikan karakter di sekolah dengan mengajarkan nilai religius, jujur, toleransi, disiplin, kerja keras, kreatif, mandiri, demokratis, semangat kebangsaan, cinta tanah air dll. d)Menumbuhkan nilai-nilai toleransi agama melalui pendidikan multikultural dengan cara melihat peranan guru yang sangat penting dalam mengimplementasikan nilai-nilai keberagaman yang inklusif dan moderat di sekolah.

\section{E. Daftar Pustaka}

Abdullah, M.Amin, Pengajaran Kalam dan Teologi di Era Kemajemukan: Sebuah Tinjauan Materi dan Metode Pendidikan Agama, dalam Tashwirul Afkar, Jurnal Refleksi Pemikiran Keagamaan \& Kebudayaan, No.11 Th. 2001.

Aly, Abdullah, Pendidikan Islam Multikultural di Pesantren, (Yogyakarta: Pustaka Pelajar, 2011).

Azra, Azyumardi, Pendidikan Multikultural: Membangun Kembali Indonesia Bhinneka Tunggal Ika, dalam Tsaqafah, Vol. I, No. 2, 2003.

Balai Penelitian Jakarta, Pendidikan Agama Islam dalam Perspektif Multikulturalisme, (Jakarta: Balai Litbang, 2009).

Bungin, Burhan, Metodologi Penelitian Kualitatif, (Jakarta: Raja Grafindo Persada, 2003).

Ekstrand, L.H, Multicultural Education dalam Lawrence J.Saha, International Encyclopedia of the Sociology of Education, (New york: Pergamon, 1997). 
Freire, Paulo, Politik Pendidikan: Kebudayaan, Kekuasaan, dan Pembebasan, Terj. Agung Prihantoro (Yogyakarta: Pustaka Pelajar, 2002).

Ibrahim, 'Abd al-Latif, Tasamuh al-Gharb maa al-Muslimin Fi al-'Asr al-Hadir, (Riyad: Dar Ibn al-Jawzi, 1999.

Ibrahim, Rustam, Pendidikan Multikultural: Pengertian, Prinsip, dan Relevansinya dengan Tujuan Pendidikan Islam dalam jurnal Addin, vol.7, no1, februari 2013.

Maimunah, Pembentukan Karakter Peduli Lingkungan Pada Peserta Didik di Madrasah Aliyah Serambi Mekkah Sumatera Barat dalam Proceeding International The Dynamic Of Malay Islamic World In Responding To Contemporary Global Issues UIN Raden Fatah Palembang, 2-3 Des 2016.

Majid, Abdul dan Dian Andayani, Pendidikan Karakter Prespektif Islam, (Bandung; Remaja Rosdakarya, 2011).

Majid, Nurkholis, Pluralitas Agama: Kerukunan dalam keagamaaan; (Jakarta: Kompas Nusantara, 2001).

Maksum, Ali dan Yunan Ruhendi, Paradigma pendidikan Universal di Era Modern dan Post-Modernisme (Yogyakarta: IRCiSod, 2004).

Ma'mur Asmani, Jamal, Buku Panduan Internalisasi Pendidikan Karakter di Sekolah (Yogyakarta: Diva Press, 2011).

Purwono, "Kajian Kepustakaan", dalam http://www.google.co.id (Diakses 20 Juli 2017).

Rosyada, Dede, Pendidikan Multikultural di Indonesia Sebuah Pandangan Konsepsional dalam Sosio Didaktika: Vol.1, No.1 Mei 2014.

Sada, Clarry, Multicultural Education in Kalimantan Barat; an Overview, dalam Jurnal Multicultural Education in Indonesia and South-East Asia, Edisi I, 2004.

Suparta, Mundzier, Islamic Multicultural Education: Sebuah Refleksi atas pendidikan Agama Islam di Indonesia, (Jakarta: Al Ghazali Center, 2008).

Sonia, Nieto, Languae, Culture and Teaching, (Mahwah, NJ: Lawrence Earlbaum, 2002).

Tilaar, H.A.R, Multikulturalisme: Tantangan-Tantangan Global Masa Depan Dalam Transformasi Pendidikan Nasional, (Jakarta:Grasindo2004).

Undang-Undang No.20 Tahun 2003 tentang Sistem Pendidikan Nasional dan Penjelasannya, (Yogyakarta: Media Wacana, 2003).

Yaqin, M.Ainul, Pendidikan Multikultural; Cross-Cultural Understanding untuk Demokrasi dan Keadilan, (Yogyakarta: Pilar Media, 2007). 
Zamroni, Pendidikan Untuk Demokrasi: Tantangan Menuju Civil Society, (Yogyakarta: Bigraf Publishing, 2001). 